\title{
Polygyny and strong genetic structuring within an isolated population of the wood ant Formica rufa
}

\author{
Wouter Dekoninck', Kevin Maebe ${ }^{1,3}$, Peter Breyne $e^{4}$, Frederik Hendrickx ${ }^{1,2}$ \\ I Royal Belgian Institute of Natural Sciences, Vautierstraat 29, B-1000 Brussels 2 Terrestrial ecology unit, \\ Ghent University, K. L. Ledeganckstraat 35, B-9000 Ghent 3 Department of Crop Protection, Faculty of Bio- \\ science Engineering, Ghent University, Coupure Links 653, B-9000 Ghent 4 Research Institute for Nature and \\ Forest, Kliniekstraat 25, B-1070 Brussels
}

Corresponding author: Wouter Dekoninck (wouter.dekoninck@natuurwetenschappen.be)

Academic editor: Jack Neff| Received 30 June 2014 | Accepted 30 September 2014 | Published 22 December 2014

http://zoobank.org/3E260DD9-9A82-4E34-9089-FB41C5C79E5F

Citation: Dekoninck W, Maebe K, Breyne P, Frederik Hendrickx F (2014) Polygyny and strong genetic structuring within an isolated population of the wood ant Formica rufa. Journal of Hymenoptera Research 41: 95-111. doi: 10.3897/ JHR.41.8191

\begin{abstract}
Social structuring of populations within some Formica species exhibits considerable variation going from monodomous and monogynous populations to polydomous, polygynous populations. The wood ant species Formica rufa appears to be mainly monodomous and monogynous throughout most of its distribution area in central and northern Europe. Only occasionally it was mentioned that $F$. rufa can have both polygynous and monogynous colonies in the same geographical region. We studied an isolated polydomous F. rufa population in a deciduous mixed forest in the north-west of Belgium. The level of polydomy within the colonies varied from monodomous to 11 nests per colony. Our genetic analysis of eight variable microsatellites suggest an oligo- to polygynous structure for at least the major part of the sampled nests. Relatedness amongst nest mate workers varies considerable within the population and colonies but confirms in general a polygynous structure. Additionally high genetic diversity (e.g. up to 8 out of 11 alleles per nest for the most variable locus) and high within nest genetic variance (93\%) indicate that multiple queens contribute to the gene pool of workers of the same nest. Moreover significant genetic structuring among colonies indicates that gene flow between colonies is restricted and that exchange of workers between colonies is very limited. Finally we explain how possible factors as budding and the absence of Serviformica can explain the differences in genetic structure within this polygynous $F$. rufa population.
\end{abstract}

\section{Keywords}

Formica rufa, genetic differentiation, polygyny, budding, Serviformica, habitat fragmentation

Copyright Wouter Dekoninck et al. This is an open access article distributed under the terms of the Creative Commons Attribution License (CC BY 4.0), which permits unrestricted use, distribution, and reproduction in any medium, provided the original author and source are credited. 


\section{Introduction}

Within the wood ant genus Formica s. str., monogynous colonies can only be founded when young and newly emerged queens disperse over long distances to find suitable conditions to start a new colony (Gösswald 1952, Rosengren and Pamilo 1983, Rosengren et al. 1993, Mabelis 1994). Moreover queens of the Formica rufa group are incapable of independently founding a colony. Hence, to establish a new colony, a queen must be accepted into a nest of a species belonging to the subgenus Serviformica (in Western Europe generally F. fusca), because she is unable to raise her own brood. High dispersal risks and low independent colony-founding success of individual wood ant queens are expected to promote a polygynous situation wherein daughter queens are adopted into the queens nest. This strategy is often accompanied by budding of the colony, whereby mated females of polygynous populations leave their natal nests with workers, and found a new nest in the vicinity of the ancestral nest. In particular when these queens have mated with males originating from outside the colony, such colony reproduction may strongly reduce the intranest relatedness within an ant population and even lead to multicolonial populations comprising several colonies each with several nest units that may or may not exchange workers.

Some western and northern European populations of mound building and other Formica species exhibit considerable intraspecific variation in colony founding and social structure within one region [for Formica exsecta (Seppä et al. 2004); Formica truncorum (Bargum et al. 2004); Formica aquilonia (Pamilo et al. 2005); Formica lugubris (Mäki-Petäys et al. 2005) and Formica selysi (Chapuisat et al. 2004)]. In some extreme cases, even "unicolonial" populations or supercolonies (Helanterä et al. 2009), where boundaries between populations are virtually absent, have been observed within the genus Formica (Chapuisat et al. 2005, Holzer et al. 2006, 2009, Bezděčková and Bezděčka 2011).

Shifts in the social structure of wood ant species are most commonly observed between populations living in nearby woodland patches that differ in management, vegetation characteristics or degree of isolation (Gyllenstrand and Seppä 2004). As these differences in social structure are frequently associated with a marked phenotypic divergence in morphological traits of the queen (i.e. the polygyny syndrome sensu Keller 1993), local adaptation to changing environmental conditions is frequently considered to be a main factor that allows intraspecific variation in social structure of wood ants (Seppä and Pamilo 1995, Mäki-Petäys et al. 2005, Holzer et al. 2006, Sorvari and Hakkarainen 2007a,b).

During the last decade, only a few studies reported extreme differences in social structure within a single ant population (Pirk et al. 2001, Chapuisat et al. 2004, Bargum et al. 2007, Kümmerli and Keller 2007, Saapunki et al. 2008). This persistence of sympatric social divergence within ant populations still remains poorly understood.

The social structure of Formica rufa, a wood ant species presumed to be monogynous throughout its distribution area, was studied in detail only once so far. Gyllenstrand et al. (2004) concluded that not all studied F. rufa colonies in Sweden are monogynous and 
that their estimates of worker relatedness suggest a mix of polyandrous single queens nests and nests with a few coexisting queens. Indeed, other studies also mention that $F$. rufa might be very exceptionally polygynous (Seifert 1991, Seifert et al. 2010, Bezděčková and Bezděcka 2011) but genetic studies at colony level are lacking. In some regions of northern Belgium, both monodomous and oligodomous populations of the presumed monogynous species Formica rufa occur in highly fragmented, small forest habitats embedded within an agricultural matrix (Dekoninck et al. 2010). In this hostile matrix it is unlikely that dispersing young queens will encounter remote and isolated, suitable forest fragments. If habitat patches are too distant from each other to be bridged by dispersing queens, long distance dispersal will not be favoured (Rosengren et al. 1993, Mabelis 1994, Höfener et al. 1996). Consequently, even if dispersal is only successful within these suitable small patches, this may in the long term result in extinction of Serviformica ants due to the repeated parasitism by young queens and competition from neighbouring ant nests (Mabelis 1984, Czechowski and Vepsäläinen 1999, Czechowski and Markó 2006, Dekoninck et al. 2010). At one particular site in this wood ant hostile agricultural matrix, colonies of a $F$. rufa population vary extremely in degree of polydomy; multiple queens are often observed in a single nest and observations of nuptial flights and Serviformica are lacking. These preliminary observations suggest that this population might be another example of a shift in social organization of a wood ant, and in particular in a wood ant species that appears to be mainly monodomous and monogynous throughout most of its distribution area (Seifert et al. 2010).

Here in this study, our first aim was to infer by means of microsatellites if $F$. rufa shifted its social structure towards polygyny in this hostile fragmented forest complex. Second, we investigated the genetic structure of the population and explain its consequences. Furthermore, we analysed the variation in number of queens and number of interconnected nests in this population by relating intranest relatedness with the degree of polydomy and its persistence over multiple years. Finally we discussed the impact of budding and the lack of Serviformica in this context.

\section{Material and methods}

\section{Study area}

The Formica rufa population included in this study is situated in the forest of the Sixtusbossen at Poperinge-Vleteren (south of Western Flanders, Belgium) (Fig. 1). Former observations (Loones et al. 2008) showed that colonies within this populations vary in degree of polydomy and that multiple queens are often observed in a single nest, which suggests that multiple queens are present within most nests. New nests are primarily formed by budding from existing ones. Nuptial flights are short ranged and probably only performed by males. Copulations were only observed in the immediate vicinity of, and on the nest mounds. A relatively unique feature of the population is that Serviformica species, which are necessary for independent colony founding in F. rufa, have 


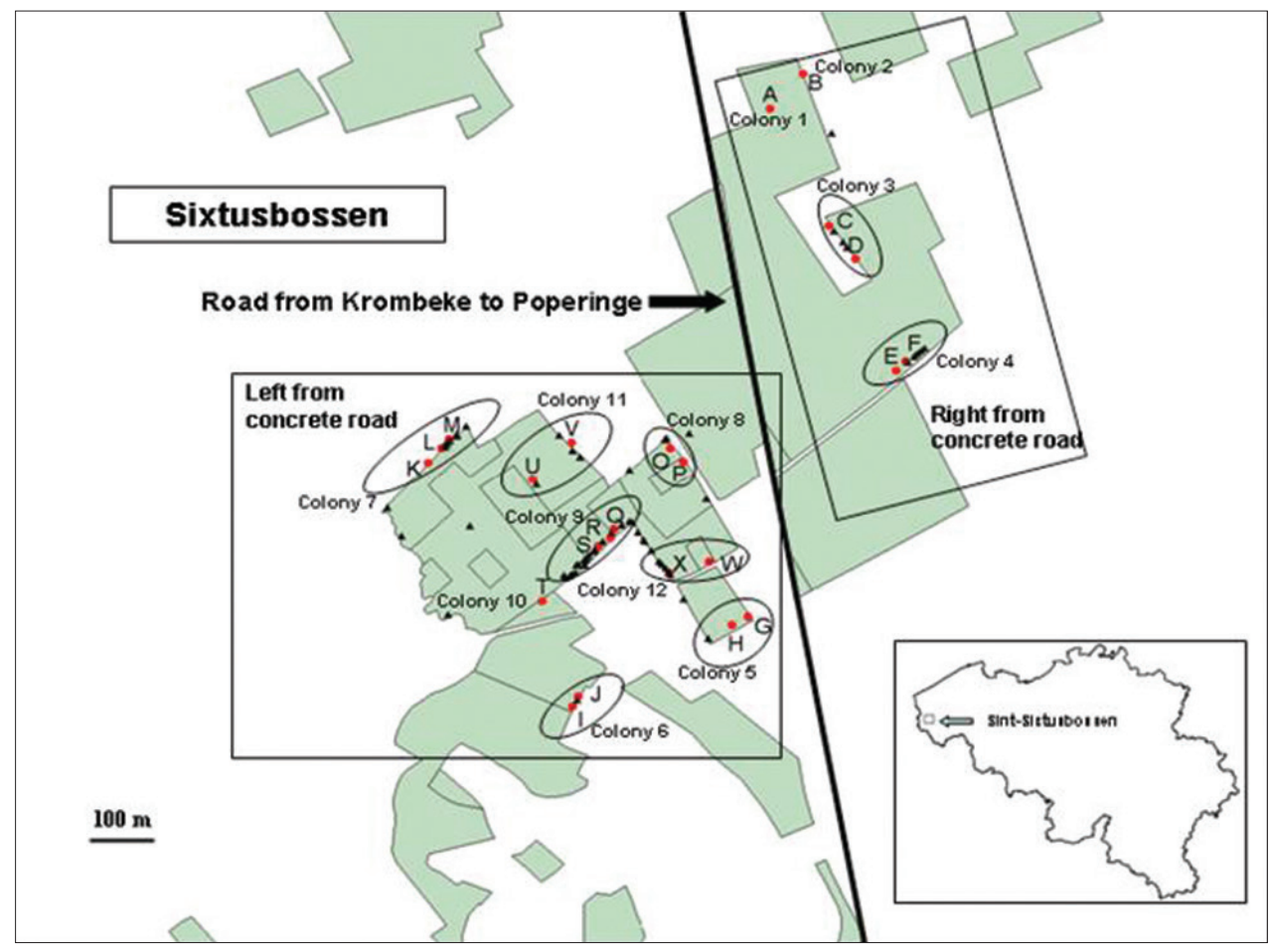

Figure I. All nests in the woodland patches of the Sixtusbossen in 2005-2006. Red • are nests that have been sampled for genotyping, $\boldsymbol{\Delta}$ are the positions of the remaining nests present during the time of sampling.

never been found in the forest stands of the Sixtusbossen (Loones et al. 2008) and the closest known Serviformica population is located at least $15 \mathrm{~km}$ away from the Sixtusbossen (Dekoninck et al. 2003).

\section{Sampling design}

Workers were sampled at different hierarchical levels to investigate the social structure and degree of genetic differentiation (Fig. 1). The isolated set of forest fragments that cover the Sixtusbossen was considered as the entire population. Within this population, between 20 and 37 workers were sampled from 23 separate nest mounds during spring 2005. The distance between two nests ranged from $5.7 \mathrm{~m}$ (nest $\mathrm{O}$ to nest $\mathrm{P}$ ) to $1200 \mathrm{~m}$ (nest B to nest I).

Spatial separation and detailed observations during the last 10 years (Loones et al. 2008) allowed us to group nests into at least 12 colonies (C1-C12). Nests are considered as belonging to the same colony if historical observations revealed that they originated from budding from a former single nest. Colonies were further defined as nest aggregations based on spatial separation caused by the different forest patches 
and forest edges and by following interconnecting trails. When a colony consisted of multiple nests, two or three nests were sampled.

Monitoring and detailed mapping of the nests during the past ten years (Loones et al. 2008) revealed that in one of the larger fragments, the number of nests increased from 29 in 1996 to 52 in 2006.

We also investigated temporal variation in genetic structure and relatedness by resampling two monodomous nests in the summer of 2009 (nest J and S) shortly after they budded and produced one and three daughternests respectively. For comparison, we also included nest I, which remained monodomous during these five consecutive years.

\section{Molecular analysis}

All sampled workers were stored in $97 \%$ ethanol until DNA extraction. DNA was extracted from the legs of adult workers in $200 \mu \mathrm{l} 6 \%$ Chelex (Biorad, Instagene Ma$\operatorname{trix}^{\mathrm{TM}}$ ) and $10 \mu \mathrm{l}$ proteinase $\mathrm{K}$ (Qiagen), incubated for two hours at $55^{\circ} \mathrm{C}$ and subsequently for $15 \mathrm{~min}$ at $97^{\circ} \mathrm{C}$. Extracted DNA was kept frozen at $-20{ }^{\circ} \mathrm{C}$.

Specimens were genotyped with 8 microsatellite loci originally designed for $F$. exsecta: FE13, FE19, FE37, FE38 (Gyllenstrand et al. 2002) and for F. paralugubris: FL12, FL20, FL21 and FL29 (Chapuisat 1996).

Polymerase chain reactions (PCR) were carried out in $10 \mu \mathrm{l}$ volumes. The PCRmix for both FE13, FE19 and FE37 contained: $0.5 \mu$ DNA, 1× PCR buffer (Qiagen), $1 \times$ Q-solution (Qiagen), $0.5 \mathrm{mM} \mathrm{MgCl}_{2}$ (Qiagen), $100 \mu \mathrm{M}$ dNTP (Fermentas), 0.4 $\mu \mathrm{M}$ forward and reverse primer and 0.5 U Taq polymerase (Qiagen). The other primers (FE38, FL12, FL20, FL21 en FL29) were used in a multiplex with $0.5 \mu \mathrm{M}$ F\&R FL20-primer, $0.2 \mu \mathrm{M}$ F\&R for the 4 other loci and 1× MP Master Mix (Qiagen). We repeated the samples that did not amplify the first time by adding $0.16 \mathrm{mg} / \mathrm{ml} \mathrm{BSA}$ $(100 \times)$ to the PCR mix and using only $0.25 \mu$ DNA.

PCR amplification was performed under the following cycling conditions: initial denaturing at $94^{\circ} \mathrm{C}$ for $3 \mathrm{~min}$ followed by 35 cycles of denaturing at $94^{\circ} \mathrm{C}$ for $45 \mathrm{~s}$, annealing at $50^{\circ} \mathrm{C}\left(\mathrm{FE} 13, \mathrm{FE} 19\right.$, and FE37) or at $55^{\circ} \mathrm{C}(\mathrm{FE} 38, \mathrm{FL} 12$, FL20, FL21 and FL29) for $45 \mathrm{~s}$ and extension for $1 \mathrm{~min}$ at $72{ }^{\circ} \mathrm{C}$ followed by a last extension step of 10 $\min$ at $72{ }^{\circ} \mathrm{C}$. Products were resolved and visualized by capillary electrophoresis on a SCE 9610 genetic analyzer (Spectrumedix) and using the Genospectrum 3.0.0 Software.

\section{Data analysis}

The GENEPOP software package (Raymond and Rousset 1995) was used to calculate observed heterozygosity $\left(H_{\mathrm{O}}\right)$, expected heterozygosity $\left(H_{\mathrm{E}}\right)$, and test for HardyWeinberg equilibrium and population differentiation (Goudet et al. 1996). FSTAT was also used to calculate fixation index $\left(F_{\mathrm{ST}}\right)$ between pairs of colonies. 
For each nest, we extracted information about (i) the degree of polygyny, (ii) the degree of genetic differentiation at the different hierarchical levels, (iii) relatedness amongst worker nestmates and (iv) population viscosity. Besides relatedness amongst nest mate workers, we used an alternative method to infer the number of queens that contributed in worker reproduction. This was done by identifying the absolute minimum number of queens (hereafter called AMQ) necessary to result in the observed worker genotypes per colony. This was performed by first assuming that only one single queen founded the colony, without restrictions on the degree of polyandry. If the given genotype data per colony did not fit with this assumption, there was evidence that the workers originated from at least a second queen and so forth. Although we realized that the number of queens obtained by this method clearly underestimates the effective number of reproducing queens as different queens can have identical alleles, it does not falsely reject the null hypothesis of monogyny.

When polygynous nests recruit their own daughters as new reproductives and relatedness between nestmate queens equals that among workers $(r)$, the effective mean number of queens per colony or nest (hereafter called $\mathrm{Qn}$ ) is a function of relatedness: $\mathrm{Q} n=(1+2 / \mathrm{m}-\mathrm{r}) / 3 \mathrm{r}$ where $\mathrm{m}$ is the effective paternity (Pamilo 1993, Seppä 1994, Gyllenstrand et al. 2004). For a typical Formica rufa nest, the effective paternity has been estimated to be 1.47 (Boomsma and Sundström 1998) giving the expected relatedness of 0.59 among the single-queen brood; a relatedness of 0.1 for oligogyne $(Q n=7)$ brood and 0.0079 for very polygynous brood $(\mathrm{Q} n=100)$.

The genetic relatedness among individuals within a nest was estimated by means of the relatedness estimator developed by Queller and Goodnight (1989) with the program GenAlEx6 (Peakall and Smouse 2006). Relatedness records the degree of shared genetic material between individuals of the same nest with respect to randomly taken individuals from the total population.

Testing the correlation between relatedness and level of polydomy was performed by means of an exact Spearman rank order correlation (StatXact v.5). To avoid pseudoreplication of nests within a colony, only the average intranest relatedness per colony was used $(\mathrm{n}=12)$.

Patterns of genetic differentiation between nests $(\mathrm{N})$ and colonies $(\mathrm{C})$ were first investigated by means of visual inspection of a principal component analysis (PCA). This PCA was performed on average allele frequencies per nest with the programme GenAlEx6 (Peakall and Smouse 2006). Genetic structure of the population was further investigated using Wright's $F$-statistics and average $F_{\text {IN }}$ (among individuals within nests), $F_{\text {NC }}$ (among nests within colonies) and $F_{\mathrm{CT}}$ (among colonies within the population) were calculated. The significance of these $F$-statistics was tested by comparing the observed values against the null distribution as obtained by random permutation. The total genetic variation was partitioned according to these different hierarchical levels by means of Analysis of Molecular variance (AMOVA) with the program Arlequin version 3.0 (Excoffier et al. 2005).

Limited dispersal of individuals from their birth place results in genetic viscosity (Hamilton 1964). This induces genetic differentiation between geographically distant groups and consequently increases relatedness among neighbours. Genetic differentia- 
tion in relation to geographic distance was investigated with a Mantel test (Liedloff 1999). This relationship was compared between nests from the same colony as well as between nests from different colonies. Comparing both relationships reveals whether the expected lower genetic differentiation between nests from the same colony are merely due to their limited geographic distance or due to the direct effect of an increased genetic relatedness of the budded nest.

\section{Results}

\section{Hardy-Weinberg equilibrium and genetic diversity}

We did not find significant differences between observed and expected genotype frequencies and hence no deviation from the Hardy-Weinberg equilibrium. Genetic diversity, calculated as expected heterozygosity $\left(H_{\mathrm{E}}\right)$ at the nest level, ranged from 0.296 in the monodomous colony A up to 0.557 in a nest from a polydomous colony. The number of alleles per locus ranged from 1 (several loci) to 8 (FL20) at the nest level and from 3 (FE19) tot 11 (FL20) for the total population. When focussing on the most diverse locus FL20, most nests contained more than $50 \%$ of the total number of alleles observed in the total population (11).

\section{Polygyny or monogyny estimation based on the AMQ, Qn and genetic relatedness}

For the majority of the investigated colonies, the observed worker genotypes did not match with reproduction by a single queen based on AMQ (Table 1). For only five out of 23 nests, no clear evidence for polygyny could be observed. Worker genotypes from 14 nests originated at least from two different queens and for 4 nests even from three different queens. When assuming that this is the true number of queens that gave rise to these worker genotypes, the obtained levels of polyandry were unrealistically high (for example nest A, 1 queen would have mated with at least 4 different males) and hence indicates that these numbers clearly underestimate the effective number of reproductive queens within a single nest.

Relatedness estimates differed substantially among nests within the population and even within colonies and ranged from 0.49 to -0.218 . Negative relatedness estimates indicates that individuals are more different than average individuals in the population. These values represent most likely random variation of estimates which are close to 0 . With this estimation of relatedness we calculated Qn. In general, this parameter confirmed the polygyn levels seen with AMQ, as for most of the nests the Qn indicate a polygynous structure. Furthermore, three nests (nest A, B and P) of which the AMQ suggested they might be monogynous nests, had a Qn between 1 and 2. Unfortanatly, we could not calculate $Q n$ for each nest and this for two resaons. (i) For nest $C$, the relatedness estimate approaches zero and consequently the estimate of $\mathrm{Qn}$ approaches 
Table I. The number of workers analysed for each nest and the number of the colony, the maximum number of allels per locus, the level of polydomy within the colony, the absolute minimum number of queens (AMQ), relatedness (r) and the estimated queen number according to Boomsma and Südström (1998) for all genotyped nests.

\begin{tabular}{c|c|c|c|c|c|c}
\hline Nest (subpop) & N workers & Max number of alleles $^{\mathbf{1}}$ & Level of Polydomy & AMQ & r & Queen number \\
\hline $\mathrm{A}(1)$ & 20 & $6(55 \%)$ & 1 & 1 & $0.493 \pm 0.060$ & 1.26 \\
\hline $\mathrm{B}(2)$ & 20 & $4(36 \%)$ & 1 & 1 & $0.395 \pm 0.044$ & 1.66 \\
\hline $\mathrm{C}(3)$ & 30 & $8(73 \%)$ & 5 & 2 & $0.009 \pm 0.047$ & 87.09 \\
\hline $\mathrm{D}(3)$ & 22 & $5(45 \%)$ & 5 & 1 & $0.242 \pm 0.043$ & 2.92 \\
\hline $\mathrm{E}(4)$ & 34 & $7(64 \%)$ & 7 & 3 & $0.035 \pm 0.035$ & 22.15 \\
\hline $\mathrm{F}(4)$ & 20 & $6(55 \%)$ & 7 & 3 & $0.068 \pm 0.057$ & 11.24 \\
\hline $\mathrm{G}(5)$ & 20 & $8(73 \%)$ & 3 & 2 & $0.089 \pm 0.057$ & 8.51 \\
\hline $\mathrm{H}(5)$ & 20 & $8(73 \%)$ & 3 & 2 & $0.160 \pm 0.061$ & 4.58 \\
\hline $\mathrm{I}(6)$ & 37 & $7(64 \%)$ & 3 & 2 & $0.037 \pm 0.028$ & 20.93 \\
\hline $\mathrm{J}(6)$ & 20 & $6(55 \%)$ & 3 & 2 & $-0.068 \pm 0.080$ & $\mathrm{NA}$ \\
\hline $\mathrm{K}(7)$ & 20 & $7(64 \%)$ & 10 & 2 & $0.351 \pm 0.046$ & 1.91 \\
\hline $\mathrm{L}(7)$ & 20 & $6(55 \%)$ & 10 & 1 & $0.290 \pm 0.052$ & 2.38 \\
\hline $\mathrm{M}(8)$ & 24 & $6(55 \%)$ & 10 & 2 & $0.038 \pm 0.058$ & 20.37 \\
\hline $\mathrm{O}(8)$ & 20 & $8(73 \%)$ & 3 & 2 & $0.085 \pm 0.047$ & 8.92 \\
\hline $\mathrm{P}(8)$ & 20 & $4(36 \%)$ & 3 & 1 & $0.445 \pm 0.056$ & 1.43 \\
\hline $\mathrm{Q}(9)$ & 20 & $7(64 \%)$ & 11 & 2 & $-0.149 \pm 0.076$ & $\mathrm{NA}$ \\
\hline $\mathrm{R}(9)$ & 20 & $8(73 \%)$ & 11 & 2 & $-0.012 \pm 0.063$ & $\mathrm{NA}$ \\
\hline $\mathrm{S}(9)$ & 20 & $8(73 \%)$ & 11 & 3 & $-0.033 \pm 0.069$ & $\mathrm{NA}$ \\
\hline $\mathrm{T}(10)$ & 19 & $6(55 \%)$ & 1 & 2 & $0.164 \pm 0.051$ & 4.46 \\
\hline $\mathrm{U}(11)$ & 20 & $5(45 \%)$ & 6 & 2 & $-0.218 \pm 0.080$ & $\mathrm{NA}$ \\
\hline $\mathrm{V}(11)$ & 20 & $5(45 \%)$ & 6 & 2 & $0.062 \pm 0.053$ & 12.36 \\
\hline $\mathrm{W}(12)$ & 20 & $7(64 \%)$ & 6 & 2 & $-0.149 \pm 0.056$ & $\mathrm{NA}$ \\
\hline $\mathrm{X}(12)$ & 20 & $8(73 \%)$ & 6 & 3 & $0.124 \pm 0.061$ & 6.01 \\
\hline
\end{tabular}

${ }^{1}=$ the $\%$ of total number alleles for this locus in the population

infinite. (ii) Due to negative relatedness estimates, Qn could not be retrieved for six other nests. Therefore, they are all marked with NA in Table 1 . However, this still means that the estimate of $\mathrm{Q} n$ is very large (or approaches infinite).

\section{Relatedness versus level of polydomy}

The correlation between the average intranest relatedness per colony $(\mathrm{n}=12)$ and the level of polydomy was significantly negative $\left(r_{\mathrm{S}}=-0.61, p=0.04\right.$, Fig. 2$)$, indicating that monodomous colonies had a significantly higher relatedness. Although the average relatedness of highly polydomous colonies approached zero, relatedness of some nests within these highly polydomous colonies was much higher, suggestiong lack of random mating. 


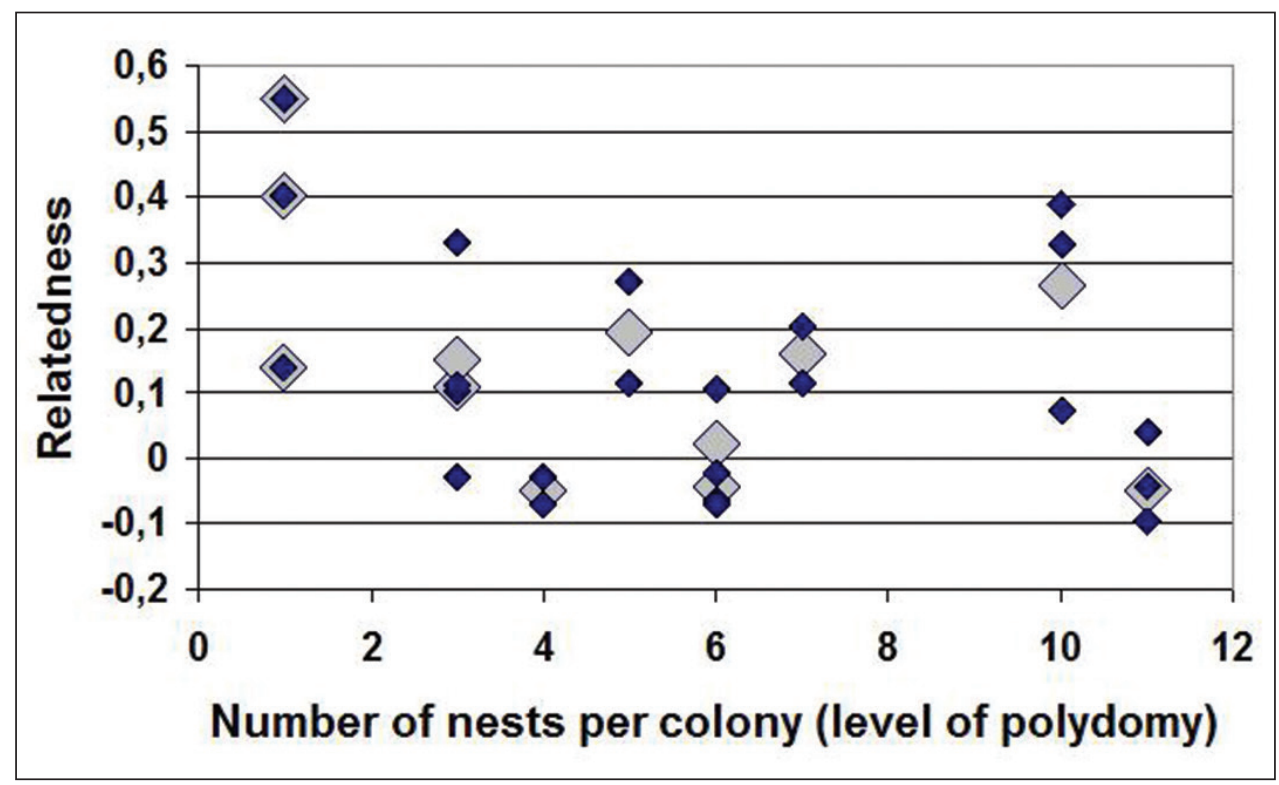

Figure 2. Correlation between the relatedness and the level of polydomy. Large grey symbols are the average intranest relatedness per colony, smaller dark symbols are estimated genetic intranest relatedness per nest.

\section{Genetic structuring}

Visual inspection of the PCA revealed, in general, that nests from the same colony (e.g. C11) were often more similar in allele frequency compared to nests from different colonies (Fig. 3). However, substantial genetic variation in allele frequency still remained among nests within a colony, suggesting their independent genetic structure (e.g. nests from C4 and C7).

Hierarchical analyses of variance indicated that the major part of the total genetic variation $(93.5 \%)$ was found within nests. Genetic variation among nests within colonies was low $\left(F_{\mathrm{NC}}=0.027\right)$ and explained $1.72 \%$ of the total genetic variation. This estimate was significantly higher $(\mathrm{p}<0.0001)$ than expected from random mating among nests members within a colony. At the highest hierarchical level, differentiation among colonies was higher $\left(F_{\mathrm{CT}}=0.077\right.$ and $\left.\mathrm{p}<0.0001\right)$ and contributed to $4.88 \%$ of the total genetic variation. The within nest inbreeding coefficient $F_{\text {IN }}$ was estimated as -0.004 and not significantly different from zero $(\mathrm{p}=0.5)$.

To investigate whether the lower differentiation among nests within colonies is merely an effect of larger distances between nests of different colonies, we compared the relationship between Nei's genetic distance and geographic distance of pairs of intracolonial nests and pairs of intercolonial nests (Fig. 4). For intracolonial nest comparisons, the Manteltest showed no obvious relationship between genetic distance and geographic distance (all exept one genetic distance below 0.1 ). This pattern contrasted 


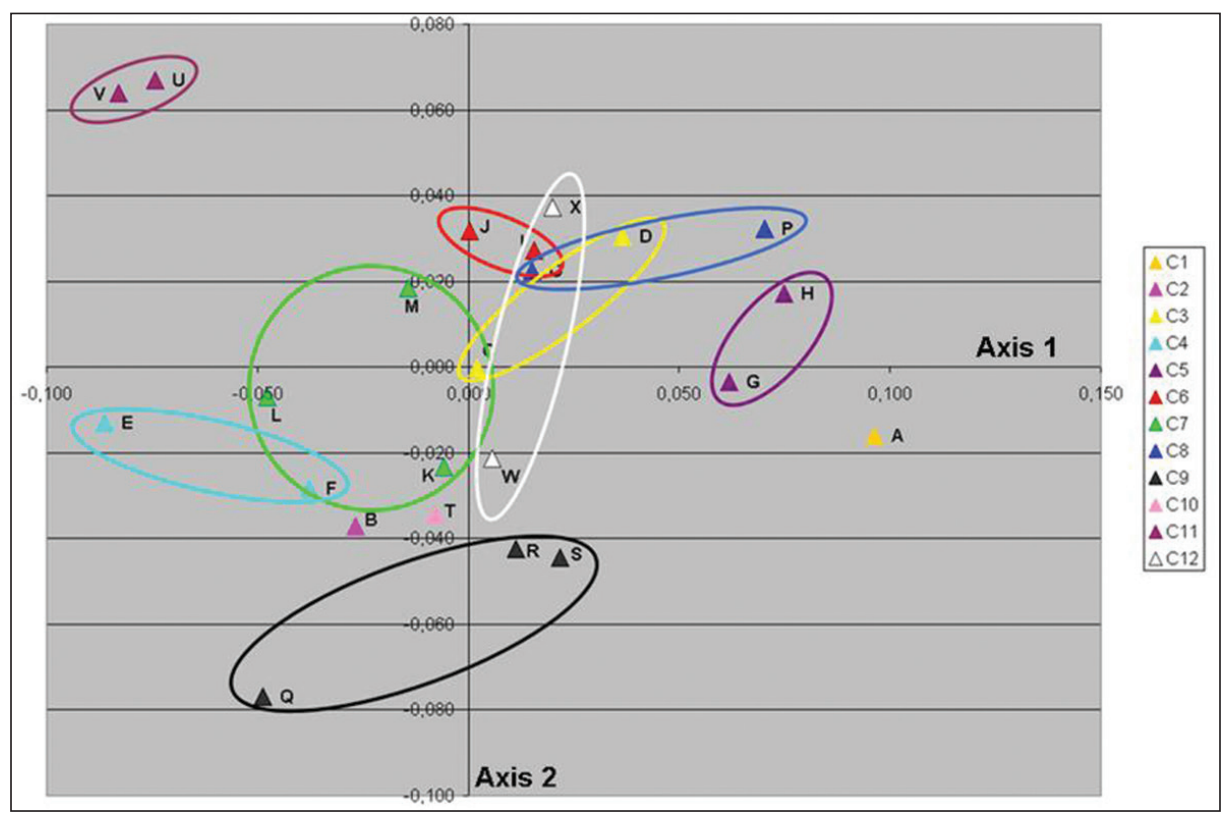

Figure 3. Genetic structure of the Formica rufa population at Sixtusbossen as revealed by Principal Component Analysis of the allele frequencies per nest. Nests with the same colour originate from the same colony. First and second PCA axes explained $36.5 \%$ and $20 \%$ of the total among nest genetic variation, respectively.

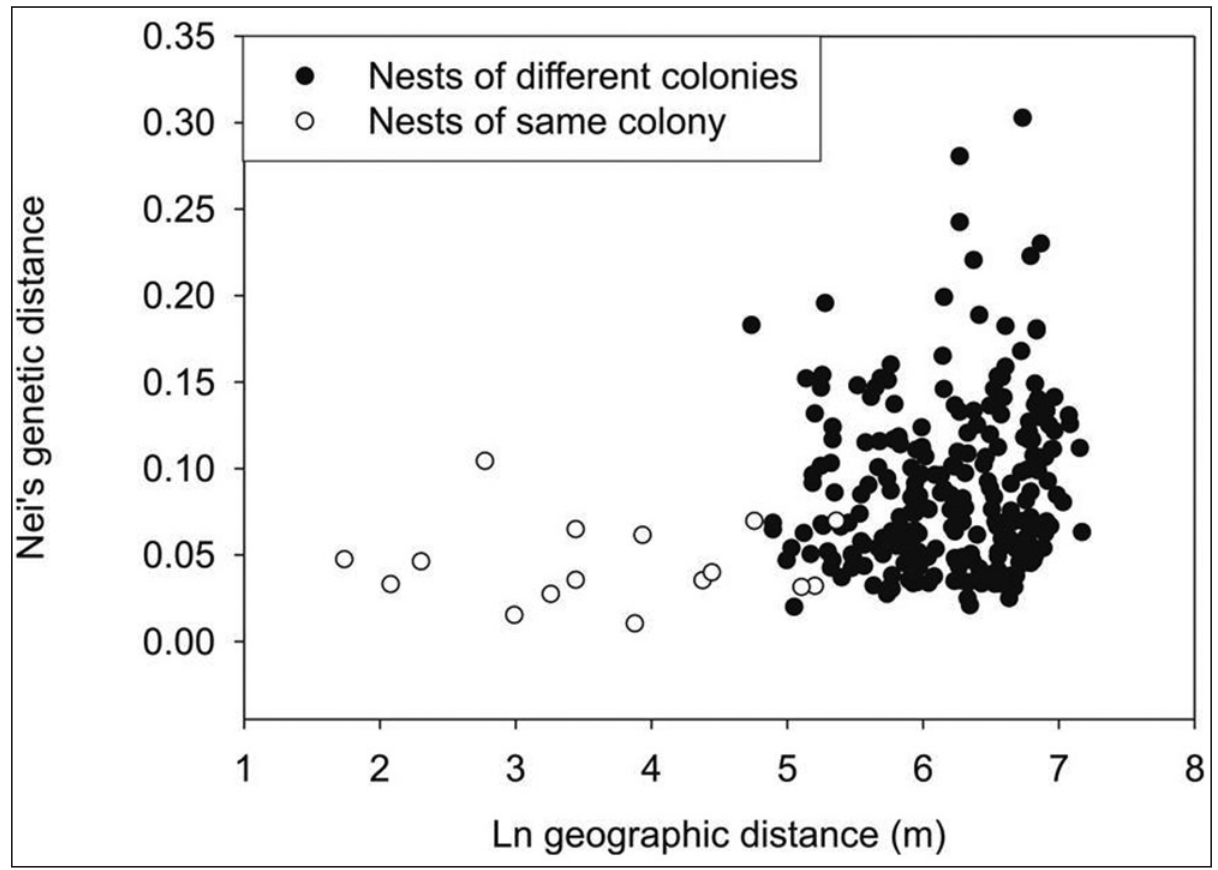

Figure 4. Manteltest showing the relationship between the Nei genetic distance and the geographical distance $\operatorname{Ln}(\mathrm{m})$. 


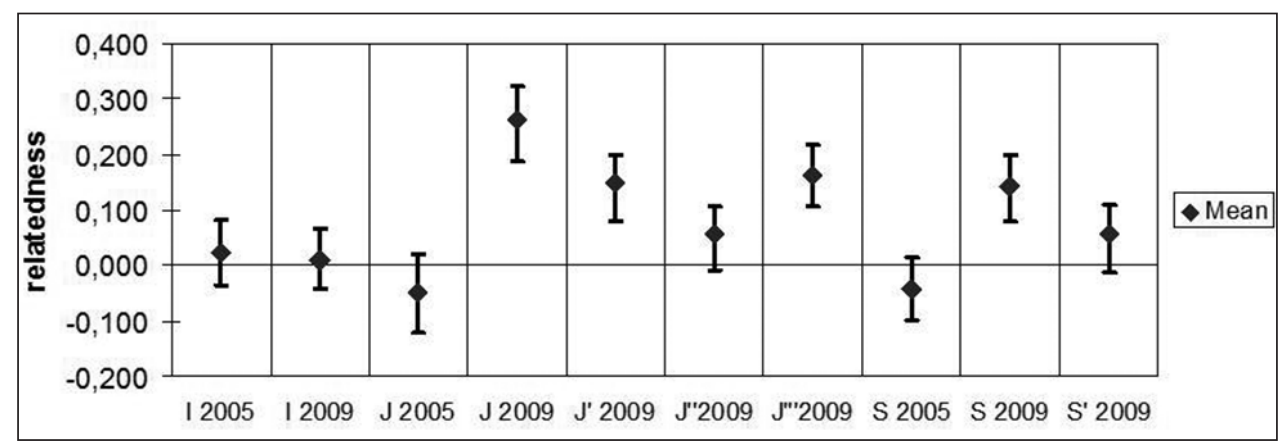

Figure 5. Mean relatedness values of the nests sampled in 2005 and 2009 and their daughternests in 2009.

with the intercolonial nest comparisons, wherein nests located at a comparable geographic distance (about $200 \mathrm{~m}$ ) as intercolonial nests, often showed a genetic distance higher than 0.10 .

\section{The impact off budding on relatedness}

The relatedness of the mother nests that had budded between 2005 and 2009 (nest $\mathrm{J}$ and $S$ ) has increased significantly $(p<0.001)$ in 2009 (respectively from -0.050 to 0.262 and from -0.042 to 0.142 ; Fig. 5). Moreover the relatedness of the daughter nests J', J", J'" and S' also show a positive relatedness that is higher than the relatedness of the mothernest in 2005. The relatedness of nest I where no budding was observed in 2009 has decreased.

\section{Discussion}

In this forest complex where opportunities for independent colony founding are virtually absent, our results demonstrated that the presumed monogynous species Formica rufa has shifted its social structure towards polygyny for at least a part of the population. This polygynous social structure results in a strong reduction of the intra-nest relatedness and the majority of the colonies showed relatedness values that were only marginally higher than zero. The average intra-nest relatedness of worker nestmates in the population was $0.129 \pm 0.014$, suggesting weak polygyny (Rosengren et al. 1993). This loss of genetic identity within colonies was confirmed by the distribution of the genetic variation, wherein almost all of the genetic variation within the population (93.5\%) was observed within colonies. Remarkably, some colonies still attained high relatedness values that are primarily observed among workers of monodomous colonies. The number of different alleles in these colonies is still considerably higher than expected under a single queen - single male mating scenario. This suggests that the 
high relatedness observed in these monodomous colonies is most likely due to adoption of daughter queens from inside the colony.

The effective number of queens per colony can be inferred from estimates of the relatedness of workers within a colony (Pamilo 1985, Queller 1993, Seppä 1994, Keller 1995) and here it ranges from 1 to infinite. This estimator however relies on strong assumptions about the degree of polyandry and population structuring, which could not be validated in this study. A high relatedness within a nest or colony for example does not necessarily imply a low absolute number of queens. If all reproducing queens have similar genotypes this results in high relatedness and hence estimates of a low number of queens. Therefore we used a second estimator AMQ. Although we did not intend to estimate the effective number of breeding queens per nest (according to Rosengren et al. (1993) this can usually not be determined because of the large nest volume) based upon AMQ, it can be expected that most, if not all nests of this population, are polygynous. Our approach only revealed the absolute minimum number of queens required to reconstruct the observed worker genotypes per nest. Assuming that this equals the true number of reproducing queens that gave rise to the observed worker genotypes would however imply a strong degree of polyandry. In nests categorised as monogynous based on AMQ, up to six different alleles could be observed for the most polymorphous locus. In this case, a single queen should have mated with at least four different males. However the effective paternity has been estimated to be 1.47 for a typical F. rufa (Boomsma and Sundström 1998). Although polyandry has been observed and assumed for this species (Gyllenstrand et al. 2004), here assumed levels of polyandry would be unrealistically high. It is therefore much more likely that for nests where we could not provide unequivocal evidence for a polygynous colony structure, multiple reproducing queens generated the genotyped workers sampled at each nest.

The observed multicolonial genetic structure in this study seems to be identical to that observed in other wood ants such as Formica polyctena (Beye et al. 1997), F. lugubris (Gyllenstrand and Seppa 2003) and Formica pratensis (Beye et al. 1998).

We found a significant negative correlation between the level of polydomy and the relatedness amongst nest mate workers per nest and per colony. Interestingly, almost all sampled monodomous colonies showed relatedness estimates that were higher than 0 while polydomous colonies were on average characterised by lower relatedness estimates that, in most cases, did not differ from zero. Nevertheless, some nests within these polydomous colonies exhibited relatedness estimates that are larger than 0. Our data from the sampling and analyses of 2005 indeed point in the direction that budding probably occurs when relatedness among workers drops due to immigration of extranest males or queens. In such cases, nests of polydomous colonies with high relatedness could be recently budded nests. A restricted data set of nests resampled in 2009 suggests this. Seppä (2008) mentions in this context that if the number of reproducing queens becomes extremely high or the queens originate from very different genetic pools, the relatedness amongst queens and nest workers becomes 0 , and this induces budding. However to confirm this, a more profound and longer-term sampling and identical follow-up of the Formica rufa population in Westvleteren is necessary. 
In ant species that have a unicolonial population structure, each nest contains numerous queens, are interconnected and individuals move freely between nests (Chapuisat et al. 2005, Holzer et al. 2009). Moreover the nestmate relatedness values are often indistinguishable from zero and unicoloniality is often associated with low overall genetic variability. Elsewhere in Europe, Formica species which follow a sessile life history in a stable habitat, indeed have the potential to develop unicoloniality as was confirmed by Chapuisat et al. (2005) and Elias et al. (2005). Our study suggests that $F$. rufa has the potential to do so when a population is hosted in a isolated forest complex without Serviformica in the near environment. In the small forest patches at Westvleteren long-term domination of long-lived resources (tending of Homoptera) leads to habitat saturation so that the colony might increase continuously. However, in such cases independent colony foundation becomes increasingly difficult because of a lack of territory and food. Furthermore, independent colony foudation is completely impossible because of lack of Serviformica. This situation promotes the reacceptance of queens by the maternal colony or maybe, in some cases, even nests of nearby colonies and the establishment of networks of nests originating from budding as is typical for unicolonial ant populations (Jackson 2007). However in the field aggression and wood ant wars were sometimes observed. These wars were as described for $F$. polyctena by Mabelis (1979) and can be very intense. These wars can even be between very nearby nests from the same and sometimes from different colonies. This latter aspect is lacking in real unicolonial ant populations (Jackson 2007) or almost lacking (Holzer et al. 2006). Unicoloniality suggests limited queen dispersal and free adult worker dispersal. In general free adult worker dispersal between different colonies is not observed in Westvleteren. Probably this can be confirmed in the near future with mark-recapture measures and a comparative study of workers and eggs of summer- and winternests of several colonies (cf. Elias et al. 2005). We conclude that in Westvleteren we have a multicolonial population structure of extended family-based nests.

\section{Conclusions and further research}

Most colonies and nest of this population of Formica rufa appear to be polygynous. Moreover our genetic analyses suggest the presence of genetic structuring in the Westvleteren population. The allelic diversity was high compared to that found at the same loci in other monogynous wood ant populations elsewhere in Belgium (Flanders). Further research on a large geographic scale by extensive genetic sampling of monoand polydomous F. rufa populations in Flanders (e.g. near Bruges Dekoninck et al. 2010) could explain whether the rarely reported polygynous structure of $F$. rufa as in Westvleteren can indeed be attributed to fragmentation and/or lack of Serviformica ants like Formica fusca. Our results indicate that more detailed temporal analyses of relatedness at the nest and colony levels for this and other wood ant species, will teach us more about the driving factors that might induce a shift in social structure (here from monogynous to oligogynous and polygynous) and variation within one population. 


\section{Acknowledgements}

We are particularly grateful to Viki Vandomme of the Terrestrial ecology unit UGent and David Halfmaarten of the Laboratory for Genetic Analysis from the Research Institute for Nature \& Forest for their thorough help with the preparation and analysis of ant samples, Jurgen Loones for his help with the fieldwork and Izumo Yao and Carl Vangestel for comments on earlier versions of the manuscript. Jean-Pierre Maelfait unfortunately deceased during the writing of this publication and we sincerely thank him for the knowledge and enthusiasm he passed on to us and many other entomologists.

\section{References}

Bargum K, Boomsma JJ, Sundström L (2004) A genetic component to size in queens of the ant, Formica truncorum. Behavioral Ecology and Sociobiology 57: 9-16. doi: 10.1007/ s00265-004-0836-z

Bezděčková K, Bezděčka P (2011) The two largest known aggregations of mound-building wood ants Formica rufa (Hymenoptera: Formicidae). Acta rerum naturalium 11: 107-110.

Bernasconi C, Maeder A, Cherix D, Pamilo P (2005) Diversity and genetic structure of the wood ant Formica lugubris in unmanaged forests. Annales Zoologici Fennici 42: 189-199.

Beye M, Neumann P, Moritz R (1997) Nestmate recognition and the genetic gestalt in the mound-building ant Formica polyctena. Insectes Sociaux 44: 49-58. doi: 10.1007/ s000400050022

Beye M, Neumann P, Chapuisat M, Pamilo P, Moritz RFA (1998) Nestmate recognition and the genetic relatedness of nests in the ant Formica pratensis. Behavioral Ecology and Sociobiology 43: 67-72. doi: 10.1007/s002650050467

Boomsma JJ, Sundström L (1998) Patterns of paternity skew in Formica ants. Behavioral Ecology and Sociobiology 42: 85-92. doi: 10.1007/s002650050415

Chapuisat M (1996) Characterisation of microsatellite loci in Formica lugubris $B$ and their variability inother ant species. Molecular Ecology 5: 599-601. doi: 10.1111/j.1365294X.1996.tb00354.x

Chapuisat M, Bocherens S, Rosset H (2004) Variable queen number in ant colonies: no impact on queen turnover, inbreeding, and population genetic differentiation in the ant Formica selysi. Evolution 58: 1064-1072. doi: 10.1111/j.0014-3820.2004.tb00440.x

Chapuisat M (2008) Sex allocation. In: Danchin E, Giraldeau L-A, Cézilly F. Behavioural Ecology. Oxford University Press, Oxford, 467-499.

Chapuisat M, Goudet J, Keller L (1997) Microsatellites reveal high population viscosity and limited dispersal in the ant Formica paralugubris. Evolution 51: 475-482. doi: $10.2307 / 2411120$

Chapuisat M, Keller L (1999) Extended family structure in the ant Formica paralugubris: the role of breeding system. Behavioral Ecology and Sociobiology 46: 405-412. doi: 10.1007/ s002650050636 
Chapuisat M, Bernasconi C, Hoehn S, Reuter M (2005) Nestmate recognition in the unicolonial ant Formica paralugubris. Behavioral Ecology 16: 15-19. doi: 10.1093/beheco/arh128

Cremer S, Ugelvig LV, Drijfhout FP, Schlick-Steiner BC, Steiner FM, Seifert B, Hughes DP, Schulz A, Petersen KS, Konrad H, Stuffer C, Kiran K, Espadaler X, d'Ettorre P, Aktac N, Eilenberg J, Jones GR, Nash DR, Pedersen JS, Boomsma JJ (2008) The Evolution of Invasiveness in Garden Ants. PLoS ONE 3(12): e3838. doi: 10.1371/journal.pone.0003838

Czechowski W, Vepsäläinen K (1999) Plesiobiosis between Formica fusca L. and Formica aquilonia Yarr. (Hymenoptera, Formicidae). Annales Zoologici (Warszawa) 49: 125-127.

Czechowski W, Marko B (2006) Uncomfortable protection: Formica polyctena Först. shelters Formica fusca L. from Formica sanguinea Latr. (Hymenoptera: Formicidae). Annales Zoologici (Warszawa) 56: 539-548.

Dekoninck W, Vankerkhoven F, Maelfait J-P (2003) Verspreidingsatlas en voorlopige Rode Lijst van de mieren van Vlaanderen. Rapport van het Instituut voor Natuurbehoud 2003.07. Brussel, 1-191.

Dekoninck W, Hendrickx F, Grootaert P, Maelfait J-P (2010) Present conservation status of red wood ants in north-western Belgium: Worse than previously, but not a lost cause. European Journal of Entomology 107: 209-218. doi: 10.14411/eje.2010.028

Elias M, Rosengren R, Sundstrüm L (2005) Seasonal polydomy and unicoloniality in a polygynous population of the red wood ant Formica truncorum. Behavioral Ecology and Sociobiology 57: 339-349. doi: 10.1007/s00265-004-0864-8

Excoffier L, Laval G, Schneider S (2005) Arlequin (version 3.0): an integrated software package for population genetics data analysis. Evolutionary Bioinformatics Online 1: 47-50.

Gösswald K (1952) Über Versuche zur Verwendung von Hilfameisen zwecks Vermeehrung der Nützlichen kleinen Roten Waldameise. Zeitschrift fuer angewendte Entomologie 34: 1-44.

Goudet J (1995) Fstat (version 1.2) - a computer program to calculate F-statistics. Journal of Heredity 86: 485-486.

Gyllenstrand N, Seppä P (2003) Conservation genetics of the wood ant, Formica lugubris, in a fragmented landscape. Molecular Ecology 12: 2931-2940. doi: 10.1046/j.1365294X.2003.01975.x

Gyllenstrand N, Gertsch PJ, Pamilo P (2002) Polymorphic microsatellite DNA markers in the ant Formica exsecta. Molecular Ecology Notes 2: 67-69. doi: 10.1046/j.14718286.2002.00152.x

Gyllenstrand N, Seppä P, Pamilo P (2004) Genetic differentiation in sympatric wood ants, Formica rufa and F. polyctena. Insectes Sociaux 51: 139-145. doi: 10.1007/s00040-003-0720-2

Gyllenstrand N, Seppä P, Pamilo P (2005) Restricted gene flow between two social forms in the ant Formica truncorum. Journal of Evolutionary Biology 18: 978-984. doi: 10.1111/j.1420-9101.2005.00908.x

Hamilton WD (1964) The genetical evolution of social behaviour. II. Journal of Theoretical Biology 7: 17-52. doi: 10.1016/0022-5193(64)90039-6

Helanterä H, Strassmann JE, Carrillo J, Queller DC (2009) Unicolonial ants: where do they come from, what are they and where are they going? Trends in Ecology and Evolution 24: 341-349. doi: 10.1016/j.tree.2009.01.013 
Höfener C, Seifert B, Krüger T (1996) A genetic model for disruptive selection on colony social organisation, reproduction, and ecotype distribution in wood ants inhabiting different woodland habitats. Insectes Sociaux 43: 359-373. doi: 10.1007/BF01258409

Holzer B, Chapuisat M, Kremer N, Finet C, Keller L (2006) Unicoloniality, recognition and genetic differentiation in a native Formica ant. Journal of Evolutionary Biology 19: 2031-2039. doi: 10.1111/j.1420-9101.2006.01133.x

Holzer B, Keller L, Chapuisat M (2009) Genetic clusters and sex-biased gene flow in a unicolononial Formica ant. BMC Evolutionary Biology 69: 1-11.

Jackson DE (2007) Social Evolution: Pathways to ant Unicoloniality. Current Biology 17: 1063-1064. doi: 10.1016/j.cub.2007.10.031

Keller L (1995) Social life: the paradox of multiple queen colonies. Trends in Ecology and Evolution 10: 355-360. doi: 10.1016/S0169-5347(00)89133-8

Kümmerli R, Keller L (2007) Contrasting population genetic structure for workers and queens in the putatively unicolonial ant Formica exsecta. Molecular Ecology 16: 4493-4503. doi: 10.1111/j.1365-294X.2007.03514.x

Liedloff AC (1999) Mantel Nonparametric Test Calculator. Version 2.0. School of Natural Resource Sciences, Queensland University of Technology, Australia.

Loones J, Maelfait J-P, Van Rhijn J, Dekoninck W, Adriaens T (2008) De rode bosmier in Vlaanderen: voorkomen, bedreigingen en herstelmaatregelen aan de hand van een detailstudie in de Sixtusbossen (Poperinge-Vleteren). Rapporten van het Instituut voor Natuur- en Bosonderzoek, 2008(1). Instituut voor Natuur- en Bosonderzoek, Brussel, Belgium, 1-94.

Mabelis AA (1994) Flying as a survival strategy for wood ants in a fragmented landscape (Hymenoptera, Formicidae). Memorabilia Zoologica 48: 147-170.

Mabelis AA (1979) Wood Ant Wars, The Relationship Between Aggression and Predation in the red wood Ant (Formica polyctena Först.). Netherlands Journal of Zoology 29: 451-620. doi: 10.1163/002829679X00016

Mäki-Petäys H, Zakharov A, Viljakainen L, Corander J, Pamilo P (2005) Genetic changes associated to declining populations of Formica ants in fragmented forest landscape. Molecular Ecology 14: 733-742. doi: 10.1111/j.1365-294X.2005.02444.x

Pamilo P (1985) Effect of inbreeding on genetic relatedness. Hereditas 103: 195-200. doi: 10.1111/j.1601-5223.1985.tb00501.x

Pamilo P, Rosengren R (1984) Evolution of nesting strategies of ants: genetic evidence from different population types of Formica ants. Biological Journal of the Linnean Society 21: 331-348. doi: 10.1111/j.1095-8312.1984.tb00370.x

Pamilo P, Zhu D, Fortelius W, Rosengren R, Seppä P, Sundström L (2005) Genetic patchwork of network-building wood ant populations. Annales Zoologici Fennici 42: 179-187.

Peakall R, Smouse PE (2006) GENALEX 6: genetic analyses in Excel. Population genetic software for teaching and research. Molecular Ecology Notes 6: 288-295. doi: 10.1111/j.14718286.2005.01155.x

Pirk C, Neumann P, Moritz R, Pamilo P (2001) Intranest relatedness and nestmate reognition in the meadow ant Formica pratensis (R.). Behavioral Ecology and Sociobiology 49: 366-374. doi: $10.1007 / s 002650000315$ 
Queller DC (1993) Genetic relatedness and its components in polygynous of social insects. In: Keller L (Ed.) Queen number and sociality in insects. Oxford Univ. Press., Oxford, 132-152. Queller DC, Goodnight KF (1989) Estimating relatedness using genetic markers. Evolution 42: 258-275. doi: 10.2307/2409206

Raymond M, Rousset F (1995) GENEPOP (version 1.2): population genetics software for exact tests and ecumenicism. Journal of Heredity 86: 248-249.

Rosengren R, Pamilo P (1983) The evolution of polygyny and polydomy in mound-building Formica-ants. Acta Entomologica Fennica 42: 65-77.

Rosengren R, Sundström L, Fortelius W (1993) Monogyny and polygyny in Formica ants, the result of alternative dispersal tactics. In: Keller L (Ed.) Queen number and sociality in insects. Oxford Univ. Press, Oxford, 308-338.

Saapunki J, Pamilo P, Seifert B (2008) Stable coexistence of two genetic lineages in one population. International Union for the Study of Social Insects. $4^{\text {th }}$ IUSSI European Meeting, Belgium, 30 August - 4 September 2008: 1-90.

Seifert B (1991) The phenotypes of the Formica rufa complex in East Germany. Abhandlungen und Berichte des Natuurkundemuseums Görlitz 65: 1-27.

Seifert B, Kulmuni J, Pamilo P (2010) Independent hybrid populations of Formica polyctena $\mathrm{x}$ rufa wood ants (Hymenoptera: Formicidae) abound under conditions of forest fragmentation. Evolutionary Ecology 24: 1219-1237. doi: 10.1007/s10682-010-9371-8

Seppä P (1994) Sociogenetic organization of the ants Myrmica ruginodis and Myrmica lobicornis. Number, relatedness, and longevity of reproducing individuals. Journal of Evolutionary Biology 7: 71-95. doi: 10.1046/j.1420-9101.1994.7010071.x

Seppä P (2008) Do ants (Hymenoptera: Formicidae) need conservation and does ant conservation need genetics? Myrmecological News 11: 161-172.

Seppä P, Pamilo P (1995) Gene flow and population viscosity in Myrmica ants. Heredity 74: 200-209. doi: 10.1038/hdy.1995.28

Seppä P, Gyllenstrand N, Corander J, Pamilo P (2004) Coexistence of the social types: genetic population structure in the ant Formica exsecta. Evolution 58: 185-194.

Sorvari J, Hakkarainen H (2007a) Forest clearing and sex ratio in forest-dwelling wood ant Formica aquilonia. Naturwissenschaften 94: 392-395. doi: 10.1007/s00114-006-0201-3

Sorvari J, Hakkarainen H, (2007b) Wood ants are wood ants: deforestation causes population declines in the polydomous wood ant Formica aquilonia. Ecological Entomology 32: 707-711. doi: 10.1111/j.1365-2311.2007.00921.x

Sundström L, Seppä P, Pamilo P (2005) Genetic population structure and dispersal patterns in Formica ants - a review. Annales Zoologici Fennici 42: 163-177. 